\title{
TATA RIAS PENGANTIN BALI MADYA KHAS KABUPATEN JEMBRANA
}

\author{
Made Yustika Yani ${ }^{1}$, Ni Ketut Widiartini ${ }^{2}$, I Gede Sudirtha ${ }^{3}$ \\ Program Studi Pendidikan Kesejahteraan Keluarga, Fakultas Teknik dan Kejuruan \\ Universitas Pendidikan Ganesha \\ Singaraja, Indonesia \\ e-mail: \\ yustika.yanimd13@gmail.com ketut.widiartini@undiksha.ac.id \\ gede.sudirtha@undiksha.ac.id
}

\begin{abstract}
Abstrak
Penelitian ini bertujuan untuk mendeskripsikan mengenai tata rias pengantin Bali Madya khas Kabupaten Jembrana yang ditinjau dari segi tata rias wajah, tatanan rambut, busana, serta aksesoris yang digunakan. Jenis penelitian ini adalah deskriptif. Lokasi penelitian di LKP W \& W Asri. Metode yang digunakan dalam pengumpulan data adalah metode observasi dan wawancara. Instrumen penelitian menggunakan lembar observasi dan lembar wawancara. Teknik analisis data yang digunakan adalah deskriptif. Hasil penelitian ini menunjukkan tata rias wajah pengantin wanita meliputi: serinata, alis-alis, gecek, foundation, bedak, shading, eyeshadow, dan lipstik. Pengantin pria: foundation, bedak, alis-alis, eyeshadow dan lipstik. Tatanan rambut pengantin wanita meliputi: penggunaan sanggul gelung tanduk, bunga menori putih, bancangan, puspo lembo, bunga sandat emas, bunga kap, bunga cempaka putih, kuning, bunga sandat dan bunga pucuk emas. Pengantin pria: tidak ada penataan khusus, hanya rambut yang disisir rapi dan di hair spray. Busana pengantin wanita meliputi: tapih wali, kamben motif cerari kotak, selendang motif rujak boni, selendang motif mastuli hitam, selendang motif jembatan cinta. Pengantin pria: kamben, saput, stagen, umpal dan udeng. Aksesoris pelengkap pengantin wanita meliputi: subeng cerorot, kalung binar, gelang nagasatru. Pengantin pria: rumbing, bros binar, dan keris. Di setiap Kabupaten memiliki perbedaan dan ciri khas tersendiri serta memiliki 3 tingkatan dalam tata rias serta busananya. Tata rias pengantin Bali Madya khas Kabupaten Jembrana memiliki ciri khas yaitu sanggul gelung tanduk, bunga menori putih, serta busananya sebagian besar menggunakan kain tenunan khas Jembrana.
\end{abstract}

Kata Kunci: Tata Rias, Pengantin Madya, Kabupaten Jembrana

\begin{abstract}
This study aims to describe the typical Balinese Madya bridal make-up in Jembrana Regency in terms of make-up, hair, clothing, and accessories used. This type of research is descriptive. Research location at LKP W \& W Asri. The methods used in data collection are observation and interview methods. The research instrument used an observation sheet and interview guidelines. The data analysis technique used is descriptive. The results of this study indicate that the bride's make-up includes: serinata, eyebrows, gecek, foundation, powder, shading, eyeshadow, and lipstick. Groom: foundation, powder, eyebrows, eyeshadow and lipstick. The hairstyle of the bride includes: the use of a bun with horns, white menori flowers, designs, puspo lembo, golden sandat flowers, cap flowers, white cempaka flowers, yellow, sandat flowers and golden shoots. The groom: no special styling, just combed hair and hair sprayed. The bride's attire includes: tapih wali, kamben with cerari box motif, rujak boni shawl, black mastuli motif shawl, love bridge motif shawl. The groom: kamben, saput, stagen, umpal and udeng. The bride's complementary accessories include: headdress, twinkle necklaces, nagasatru bracelets. Groom: rumbing, twinkle brooch, and keris. Each district has its own differences and characteristics and has 3 levels of make-up and clothing. The Balinese Madya bridal make-up is typical of Jembrana Regency, which is characterized by a bun with horns, white menori flowers, and most of the clothes use Jembrana woven fabrics.
\end{abstract}

Keywords: Makeup, Intermediate Bride, Jembrana Regency 


\section{PENDAHULUAN}

Negara Indonesia sering disebut dengan negara kepulauan yang memiliki suku, adat istiadat, serta kebudayaan yang berbeda-beda. Perbedaan tersebut dapat mencirikan suatu daerah dilihat dari segi penggunaan bahasa sehari-hari, bentuk kesenian, hingga adat pernikahan yang dimiliki. Di Indonesia hal yang paling dipelihara dengan baik sampai saat ini adalah adat pernikahannya. Pernikahan merupakan penyatuan ikatan lahir batin antara seorang wanita dengan seorang pria yang nantinya disahkan sebagai pasangan suami istri dengan maksud membentuk keluarga baru yang bahagia lahir batin. Upacara pernikahan di Indonesia memiliki nilai kesakralan yang tinggi, dan pelaksanaannya harus sesuai dengan tata cara yang sudah di tentukan oleh daerah tersebut, salah satunya terdapat di pulau Bali. Adat pernikahan (pawiwahan) di Bali masih menjunjung tinggi nilai kesakralan dan serangkain upacaranya mengandung nilai dan arti tersendiri yang diturunkan secara turun temurun, sehingga Bali memiliki adat pernikahan yang masih kental dengan bentuk dari tata rias pernikahnnya.

Pulau Bali memiliki 8 Kabupaten di setiap Kabupaten tentunya memiliki keunikan serta ciri khas tersendiri dalam tata rias pernikannya yang dapat dilihat dari segi tata rias wajah, tatanan rambut, busana, serta aksesoris yang digunakan. Tata rias pengantin Bali secara penuh masih dibentuk dan di lihat dari tingkatan pengantin yaitu tingatan Utama (Agung), Madya (menengah), dan Nista (sederhana) dari ketiga tingkatan tersebut masingmasing memiliki perbedaan di setiap tata rias pengantinnya. Perbedaan tersebut dapat dilihat pada tata rias dan busana pengantin gaya badung yang tata rias pengantinnya menggunakan gelung moding, dan sebagain busananya menggunakan kain prada yang merupakan ciri khas dari madya Badung Dwi Pujiastuti (2015). Berbeda halnya dengan tata rias pengantin Kabupaten Kelungkung yang memiliki ciri khas yaitu menggunakan semi lilit, bunga sari konta, sanggul kletek mandel, dan sabuk bebekeng Ni Putu Putri Astuti (2017).

Pada Kabupaten Jembrana pun memiliki perbedaan di setiap tingkatannya, tata rias pengantin Agungnya menggunakan baju brluduru hitam, menggunakan bunga emas lebih banyak, dan pada pengantin laki-laki menggunakan gelang kaki Kadek Hermayani (2019). Sedangkan pada tata rias Madyanya tidak menggunakan baju bludru hitam melainkan menggunakan kain tenunan Jembrana dan tidak menggunakan gelang kakai pada pengantin prianya. Tata rias pengantin Madya Jembrana memiliki ciri khas yaitu sanggul gelung tanduk, bunga menori putih, semi capit udang, dan sebagain besar busananya menggunakan kain tenunan khas Jembrana. Dari tata rias yang sudah ada menyatakan bahwa setiap Kabupaten dan tingakatan pernikahan memiliki perbedaan dan ciri khas tersendiri.

Menurut Puspa (2013) tata rias wajah atau make-up pada sekarang ini telah menjadi bagaian dari setiap runtinitas kehidupan masyarakat moderen khususnya kaum wanita. Tujuanya yaitu menghilangkan atau dapat mengurangi cacat wajah, mempercantik wajah sehingga menghasilkan tata rias yang sesui dengan keinginan (Seriati,2011). Tata rias wajah merupakan kebutuhan utama bagi kaum wanita dengan menggunakan kosmetik guna membuat mereka lebih percaya diri dan selalu tampil cantik dan sempurna di setiap harinya. Tata rias pengantin merupakan karya budaya yang mencerminkan kepribadian bangsa, yang terwujud dalam sebuah pernikahan adat yang sakral yang memiliki spesifikasi pada bagain dahi yaitu serinata dan gecek yang memiliki makna yang sudah ada dan dipercaya sejak zaman dahulu (Agung,2004). Di dalam penggunaan tata rias pengantin Bali memiliki beberapa tingkatan yang berbeda-beda diantaranya: tata rias pengantin Utama (Agung), tata rias pengantin Madya, dan tata rias Nista. Tata rias pengantin bali Utama (Agung) dan tata rias pengantin Bali Madya, hanya dapat digunakan oleh golongan Tri Wangsa sedangkan tata rias pengantin Bali Nista digunakan oleh orang Jaba (Mahligai,2009).

Tata rias pengantin Bali Agung dan tata rias pengantin Bali Madya yang dimana pada zaman dahulu hanya dapat di pergunakan oleh kalangan Brahmana, Ksatria, dan wesia (tri wangsa), sedangkan tata rias pengantin Bali Nista dipergunakan dalam pelaksanaan upacara pernikahan dengan tingkatan upacara yang sederhana. 
Namum dengan seiring berjalannya waktu, pada saat sekarang ini pemakaian menurut aturan-aturan tersebut sudah tidak terlalu diperhatikan lagi, hal ini sangat tergantung dari kemampuan ekonomi pengantin yang akan menyelenggarakan upacara pernikahan (Agung,2004). Tata rias pengantin Bali Madya yang riasannya dikatan sederhana tetapi masih memperlihatkan kemewahan. Tata rias pengantin Bali Madya terdiri dari serinata, gecek, alis-alis, eyeshadow, dan lipstik. Langkah dalam merias wajah sebagai berikut:

1. Bersihkan wajah menggunakan susu pembersih, dan gunakan penyegar untuk menutup pori-pori

2. Aplikasikan pelembab, foundation, bedak tabur dan bedak padat

3. Bentuk alis dengan pensil alis coklat kehitaman

4. Aplikasikan eyeshadow, eyeliner, dan pasangkan bulu mata palsu

5. Aplikasikan perona pipi dan lipstik

Penataan rambut merupakan tahap akhir yang sangat penting karena penataan rambut sangat mendukung dalam penampilan diri. Menurut (Mertami,1993) penataan rambut pengantin Bali Madya desebut dengan "Semi". Semi merupakan bentuk rambut yang melengkung ke dalam atau di bagain belakang telinga yang nantinya di beri malem. Tatanan rambut pada pengantin Bali Madya yaitu: sanggul gelung moding, bunga cempaka putih, kuning, bancangan, bunga mawar, kap, dan bunga emas.

Tata busana merupakan bagaian dari tata rias dalam pengantin Bali. Masingmasing Kabupaten tentunya memiliki busana dan ciri khas tersendiri (Mertami,1993). Jadi busana pengantin Bali Madya merupakan busana yang dipergunakan oleh pengantin Bali Madya yang terdiri dari: pengantin wanitanya menggunakan tapih, kamben, sabuk, selendang prada, sabuk prada, dan pengantin prianya menggunakan kamben, kampuh, umpal dan udeng. Aksesoris merupakan barang tambahan dan sebagai pelengkap dalam berbusana. Aksesoris merupakan benda-benda yang digunakan seseorang untuk dapat mendukung atau dapat dikatakan sebagai pengganti pakaian (menurut Wikipedia). Pada tata rias pengantin Bali Madya aksesoris yang digunakan yaitu: subeng cerorot, gelang, cicin dan keris. Pada tata rias pengantin Bali Madya indentik dengan penggunakan hiasan pada dahi yang disebut dengan serinata. Serinata pada tata rias pengantin Bali Madya dibentuk dengan menggunakan ukuran atau hitungan berikut tahapannya: buatlah titik tengah dari dahi 4 jari, kemudian ukur 2 jari ke kiri dan kanan mulai dari titik tengah tersebut, ukur ketinggian alis 1 ibu jari, kemudian hubungkan titik-titik yang telah dibuat, selanjutnya periksa kembali akan seimbang antara kiri dan kanan, selanjutnya berikan warna menggunakan pensil alis hitam dan eyeshadow hitam.

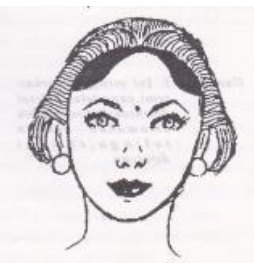

Gambar 1. Serinata

Tatanan rambut pengantin Bali Madya identik dengan penggunakan semi. Semi yang dibuat disebut dengan istilah engkug-engkugan (sunggar) yang di lengkungkan ke bagian dalam menuju kebelakang telinga. Semi di buat dengan bantuan malem untuk memperkuat semi, cara pembuatannya yaitu: rambut dibagai menjadi dua, kemudian garis membentuk tanda tanya menuju belakang telinga dengan pengambilan bagain depan menyerong kira-kira 3 jari dari garis rambut, selanjutnya berikan malem dan dibentuk melengkung kebelakang telinga seperti sunggar sambil disisir hingga rambut menjadi kaku.

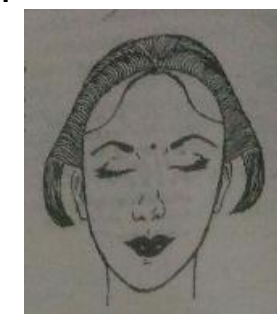

Gambar 2. Semi

Dari pemaparan diatas menyatakan bahwa tata rias pengantin memiliki ciri khas tersendiri di setiap Kabupatennya, begitu pula dengan tata rias pengantin Madya 
Jembrana memiliki ciri khas tersendiri yang dapat dilihat dari tata rias wajah, tatanan rambut, busana, serta aksesoris yang digunakan. Pada tatanan rambut identik dengan penggunakan semi yang disebut dengan semi capit udang, kemudian bunga yang digunakan pun berbeda yaitu menggunakan bunga menori putih, dan busanyanya pun sebagain besar menggunakan kain tenunan khas Jmebrana yang dapt dilihat pada motif yang digunakan. Dari latar belakang yang telah diuraikan, maka peneliti akan melakukan penelitian dengan judul "Tata Rias Pengantin Bali Madya Khas Kabupaten Jembrana" penelitian ini bertujuan untuk mendeskripsikan bagaimana tata rias wajah, tatanan rambut, busana, serta aksesoris yang digunakan pada tata rias pengantin Bali Madya Khas Kabupaten Jembrana.

\section{METODE PENELITIAN}

Jenis penelitian yang digunakan dalam penelitian ini adalah penelitian deskriptif. Penelitian ini bermaksud untuk menemukan pengetahuan yang seluasluasnya terhadap objek penelitian pada suatu masa tertentu. Menurut (Sukmadinata, 2013) menyatakan bahwa penelitian deskriptif adalah karakteristik penelitian yang mengungkapkan secara spesifik berbagai fenomena sosial dan alam yang ada di dalam kehidupan masyarakat. Penelitian ini bertujuan untuk mendeskripsikan tentang tata rias pengantin Madya Khas Kabupaten Jembrana yang lebih memfokuskan pada bentuk tata rias pengantin pria dan pengantin wanita Madya Khas Kabupaten Jembrana yang dapat dilihat dari segi tata rias wajah, tatanan rambut, busana, serta aksesoris yang digunakan. Lokasi penelitian ini dilakukan di LKP dan Salon W\&W Asri, LKP dan Salon Sekar Taji, serta Puri Agung Negara Jembrana. Informan dalam penelitian ini yaitu informan yang bergerak dalam bidang tata rias yaitu $\mathrm{Ni}$ Ketut Sumiati selaku pemiliki LKP dan Salon W\&W Asri sekaligus sebagai ketua HARPI, Ni Ketut Rustianti selaku pemilik LKP dan Salon Sekar Taji, dan terakhir ibu Ni Ketut Yuliana selaku penata rias sekaligus anggota HARPI yang semuanya berada di Kabupaten Jembrana. Variabel dalam penelitian ini adalah tata rias pengantin Madya Khas Kabupaten
Jembrana yang dapat ditinjau dari tata rias wajah, tatanan rambut, busana yang digunakan, serta aksesoris yang digunakan baik pengantin wanita maupun pengantin pria. Adapun metode yang digunakan yaitu metode observasi, adapun objek yang diobservasi dalam penelitian ini antara lain: bagian-bagian tata rias wajah, tatanan rambut, busana yang digunakan, dan aksesoris yang digunakan dalam tata rias pengantin Madya Khas Kabupaten Jembrana. Peneliti melakukan observasi dengan terjun langsung kelapangan dengan menggunakan alat bantu berupa pedoman observasi untuk mencatat objek yang diamati dan membawa kamera untuk dapat mendokumentasikan gambar yang nantinya dapat menunjang data yang akan diambil. Metode wawancara, dengan menggunakan metode ini peneliti dapat lebih mudah mendapatkan data yang akan diteliti dengan datang secara bertahap dan melakukan beberapa pertanyaan pokok yang berkaitan dengan tata rias pengantin Madya Khas Kabupaten Jembrana.

Instrumen dalam penelitiana ini adalah lembar observasi yang digunakan untuk memperoleh gambaran umum yang terkait dengan bagain-bagain dari tata rias wajah, tatanan rambut, busana serta aksesoris baik, lembar wawancara yaitu berisikan pertanyaan-pertanyaan yang digunakan untuk mengajukan pertanyaan kepada informan yang isinya mengenai bagain-bagain dari tata rias wajah, tatanan rambut, busana, serta aksesoris dan langkah-langkah dalam tata rias pengantin Madya Khas Kabupaten Jembrana. Teknik analisis data yang digunakan dalam tata rias pengantin Madya Khas Kabupaten Jembrana yaitu teknik deskriptif yang digunakan untuk menganalisis secara sistematis dengan cara mendeskripsikan data yang sudah di kumpulkan untuk dapat mengetahui tata rias pengantin Madya Khas Kabupaten Jembrana. Data yang dianalisis agar mendapatkan kesimpulan yang akurat dan pasti tentang tata rias pengantin Madya khas Kabupaten Jembrana.

\section{HASIL DAN PEMBAHASAN Hasil}

Tata rias pengantin Madya khas Kabupaten Jembrana merupakan tata rias yang digunakan pada saat acara 
pernikahaan dengan memiliki ciri khas tersendiri yang dapat dilihat dari semi yang dinamakan dengan semi capit udang, sanggul gelung tanduk, bunga menori putih, serta busana yang sebagaian besar menggunakan kain tenunan khas Jembrana. Tata Rias Pengantin Madya Khas Kabupaten Jembrana terdiri dari tata rias wajah, tatanan rambut, busana, serta aksesoris yang digunakan oleh pengantin wanita maupun pengantin pria. Peneliti melakukan observasi di LKP, Salon, Puri dan beberapa penata rias. Peneliti juga melakuka wawancara dengan Ketua HARPI, dan anggota HARPI serta penata rias yang mengetahui tentang tata rias pengantin Madya Jembrana sehingga peneliti mendapatkan informasi tentang tata rias tersebut dengan baik.

Tata rias wajah pengantin Madya Jembrana terdiri dari serinata, gecek, alisalis, eyeshadow, shading, lipstik dan perona pipi. Serinata di buat dengan menggunakan ukuran dan dibentuk sesuai dengan bentuk wajah setiap pengantin wanita, yang dibuat dengan menggunakan bantuan pensil alis warna hitam, kemudian diarsir sesuai dengan arah pertumbuhan rambut dan di baurkan menggunakan eyeshadow warna hitam. Adapun langkahlangkah dalam merias wajah untuk pengantin wanita sebagai berikut:

1. Pertama membersihkan wajah dengan dengan menggunakan milk cleanser.

2. Lalu memberikan penyegar berfungsi sebagai penutup pori-pori wajah, dan pemberian pelembab pada wajah.

3. Mengaplikasikan foundution sesuai dengan warna kulit atau warna kuning langsat untuk pengantin.

4. Selanjutnya shading menggunakan foundation warna gelap pada bagain tulang pipi, rahang hidung.

5. Kemudian aplikasikan bedak tabur dan bedak pada ke seluruh wajah dan leher, bentuk alis dengan menggunakan pensil alis warna coklat kehitaman dengan bentuk alis melengkung indah.

6. Aplikasiakan eyeshadow warna gelap atau coklat pada chourge, pada ujung mata diberikan warna hitam, mata jelopak mata berikan warna kuning keemasan. Dan pasangkan bulu mata palsu.

7. Selanjutnya aplikasikan eyeliner atas dan bawah dengan warna hitam.

8. Terakhir aplikasikan perona pipi dan lipstik, pemasangan gecek, dan pembuatan serinata pada dahi.

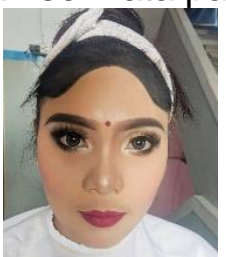

Gambar 3. Tata Rias Wajah

Tatanan rambut pada tata rias pengantin Madya Khas Kabupaten Jembrana memiliki perbedaan dengan tatanan rambut pada pengantin lainnya, yang terletak pada bentuk semi, bentuk sanggul, serta bunga yang digunakan. Tatanan rambut pengantin wanita terdiri dari: semi capit udang, bunga menori putih, bunga menori putih kuncup, bunga bacangan, bunga emas, bunga kap, puspa lembo, sanggul gelung tanduk, bunga cempaka putih, kuning dan bunga sandat. Semi capit udang merupakan bagain rambut depan yang dibentuk seperti tanda tanya yang dioleskan malem. Bunga menori digunakan karena pada zaman dulu daerah Jmebrana tidak ditemukan bunga selain bunga menori sehingga bunga itu yang dijadikan hiasan pada pengantin Madya Khas Kabupaten Jembrana. Kemuidn sanggul gelung tanduk merupakan ciri khas dari pengantin Madya Khas Kabupaten Jembrana karena pada zaman dahulu di Jembrana memiliki tradisi mekepung-kepungan yaitu atraksi balap kerbauyang dilakukan dari tahap proses pengolahan tanah sawah yaitu melumatkan tanah menjadi lumpur. Kerbau yang memiliki tanduk dikaitkan dengan sanggul yang digunakan oleh pengantin Jembrana. Sanggul gelung tanduk dibuat dari kumpulan ijuk halus yang dicampur dengan sisa rambut yang dipasang pada bagain kiri dan hairpiace yang dibentuk oval dipasang sebelah kanan. Sanggul gelung tanduk yaitu sebagai simbol keberanian, dimana lambang keberanian ini menandakan bahwa pengantin harus kuat dalam menghadapi kehidupan barunya. Untuk tatanan rambut pengantin pria tidak ada tatanan khusus dimana rambut hanya sisir 
rapi dan diberikan hair spray.

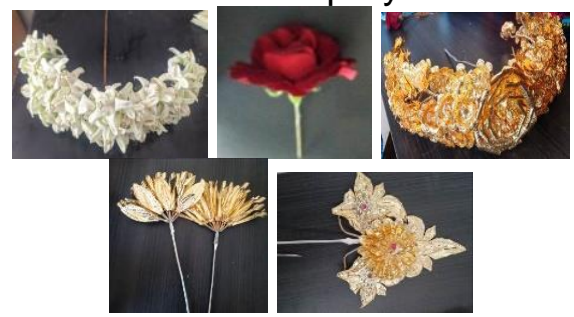

Gambar 4. Aksesoris Rambut

Langkah-langkah pembentukan tatanan rambut pengantin wanita yaitu :

1. Pertama bagi rambut menjadi dua bagian. Bagian depan di bentuk semi capit udang dan pada bagian belakang diikat rapi menggunakan karet.

2. Pasangkan cemara pendek dan kecil dan digulung dan diberikan harnet.

3. Kemudian pasangkan tanduk pada sisi kiri dan sanggul oval pada sisi kanan sedikit menyerong

4. Pasangkan bunga menori yang sudah dirangkai pada kawat yang sudah disiapkan, pasang pada bagian depan atas semi dan pasang bunga mawar merah pada bagain tengahtengah.

5. Pasangkan bancangan di atas bunga menori putih tadi, kemudian pasangkan bunga puspo lembo pada samping kanan dan kiri sejajar dengan bancangan dan pasang bunga menori kuncup pada bagain serinata.

6. Kemudian pasangkan bunga emas pada bagian atas bancangan mulai dengan jumlah 9,5,4,3,2,1 susun rapi sehingga terlihat mengkrucut ke atas.

7. Pada bagain atas dipasang bunga kap 1 tangkai menghadap ke depan, bagain belakang di tengah antara tanduk dengan hair piace pasangkan bunga cempaka putih berjumlah 20 biji, kemudian cempaka kuning berjumlah 15 biji, dan pada bagain bawah kiri di pasangkan bunga sandat sebanyak 20 biji.

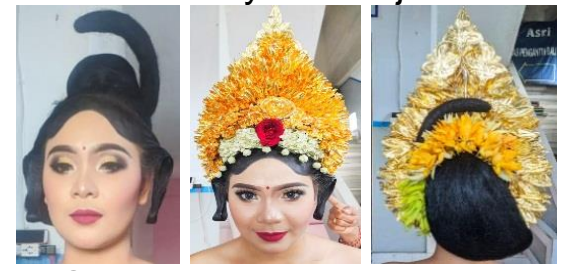

Gambar 5. Tatanan Rambut
Busana pada tata rias pengantin Madya Khas Kabupaten Jembrana sebagian besar menggunakan kain tenunan khas Jembrana. Busana pada pengantin wanita terdiri dari: tapih wali, kamen songket rmotif cerari kotak, sabuk toros, selendang tenunan motif rujak boni, selendang tenunan motif mastuli hitam, dan selendang tenuan motif Kembatan cinta. Pada pengantin pria terdiri dari: kamen, saput songket motif cerari kotak, stagen ukuran kecil, umpal, dan udeng.

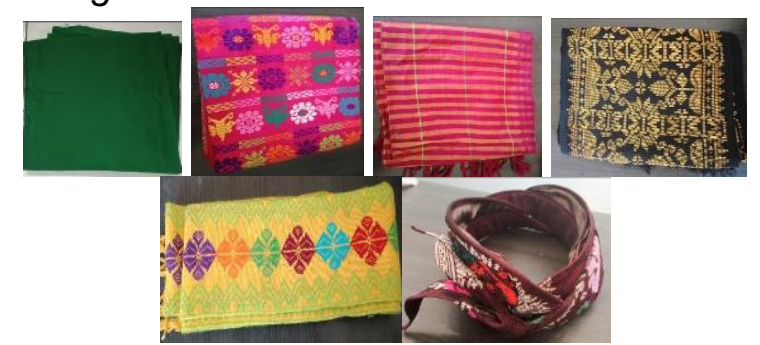

Gambar: 6. Busana Pengantin

Langkah-langkah pemasangan busana pada pengantin wanita terdiri dari:

1. Menggunakan tapih wali dengan belahan dibagain belakang, kamen songket motif cerari kotak yang digunakan sebatas mata kaki,

2. Kemudian pasangkan sabuk toros mulai dari pinggang menuju ke dada pengantin wanita, dimana pada bagain dada sabuk toros dibentuk mengikuti bentuk susu pengantin wanita,

3. Kemuidan pakaikan selendang rujak boni mulai dari pinggul sebelah kanan menuju atas tepat dibawah susu pengantin,

4. Selanjutnya pakaikan selendang mastuli hitam pada dada pengantin wanita dengan ujung atau sisa dililitkan kepinggang dengan ujung menjuntai pada sisi sebelah kanan,

5. Terakhir selempangkan selendang motif jembatan cinta pada bahu pengantin wanita.

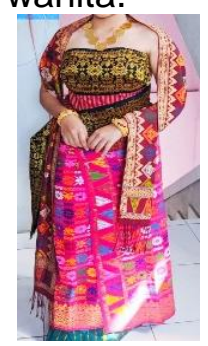

Gambar 7. Busana Pengantin Wanita

Langkah-langkah pemakain busana pada 
Jurnal Bosaparis: Pendidikan Kesejahteraan Keluarga Volume 12, Nomor 1, Maret 2021

pengantin pria yaitu:

1. Gunakan kamben yang dibentuk lelencingan pada bagain depan, kemuidan menggunakan saput cerari kotak pada bagian dada sebatas betis pada bagain dalam sisi kanan dibentuk wiru ukuran besar

2. Pasangkan stagen ukuran kecil pada bagain dada guna memperkuat saput yang sudah dipasang

3. Pasangkan umpal dengan sisi kiri menjuntai kewabah dan terakhir pasangkan udengan

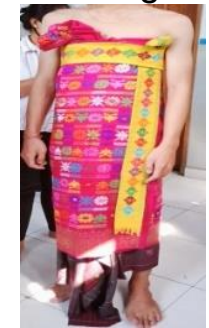

Gambar 8. Busana Pengantin Pria

Aksesoris pengantin wanita terdiri dari: subeng cerorot, kalung binar, dan gelang nagastru. Subeng cerorot merupakan hiasan telinga yang digunakan pengantin wanita yang menandakan keharmonisan pengetahuan dan sikap. Kalung binar adalah hiasan leher yang berjumlah 9 liotin yang melambangkan semakin banyak jumlah liotin sebagai tinggi tingkat status sosial seseorang tersebut. Pada pengantin pria terdiri dari: rumbing, bros binar, keris dan bunga pucuk emas. Bros binar merupakan bros yang digunakan pada pengantin pria yang berjumlah 3 liontin. Langkah penggunaan aksesoris pengantin wanita terdiri dari: subeng, kalung binar, sabuk pending, gelang nagasatru. Pengantin pria dimulai dari penggunaan rumbing, bros binar, dan keris.

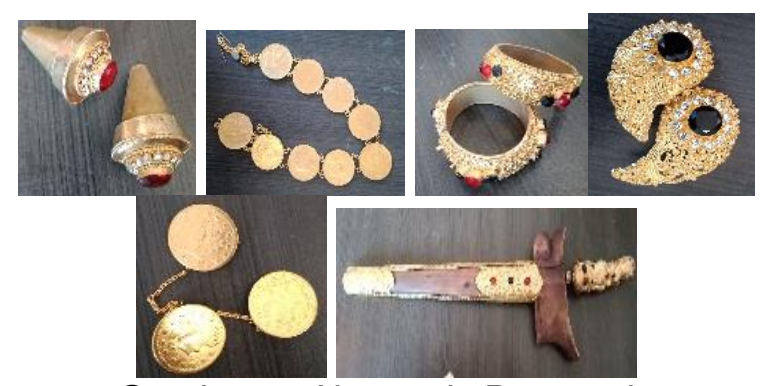

Gambar 9. Aksesoris Pengantin
p-ISSN : 2599-1434

e-ISSN : 2599-1442

Tata rias pengantin Madya khas Kabupaten Jembrana adalah tata rias yang tingkatannya berada di tengah-tengah yang digunakan dalam upacara pernikahan dan upacara potong gigi (mepandes) di Kabupaten Jembrana. Tata rias pengantin Madya khas Kabupaten Jembrana terdiri dari tata rias wajah, tatanan rambut, busana, serta aksesoris.

Tata rias wajah pengantin Madya Jembrana terdiri dari hiasan mata (eyeshadow), lipstik, serinata, alis-alis serta gecek pada dahi. Tata rias wajah yang digunakan dalam tata rias pengantin Madya khas Kabupaten Jembrana memiliki perbedaan dengan tata rias pengantin Bali Madya yaitu dapat dilihat dari serinata. Serinata memiliki fungsi sebagai hiasan dahi untuk membentuk dahi menjadi sempurna serta menambah kecantikan dan keanggunan dari pengantin wanita. Tata rias pengantin Madya khas Kabupaten Jembrana serinata dibentuk sesuai dengan bentuk wajah pengantin wanita, sedangkan untuk tata rias pengantin Bali Madya serinata dibentuk sesuai dengan rumus/hitungan yang sudah ditentukan (Mertami,1993:30). Jadi Kesimpulannya yaitu bahwa tata rias wajah pengantin Bali Madya dengan tata rias pengantin Bali Madya Jembrana memiliki perbedaan yang dapat dilihat dari pembuatan serinatanya. Tata rias wajah pengantin Bali Madya khas Kabupaten Jembrana untuk pengantin wanita meliputi: penggunaan foundation, bedak, shading, eyeshadow, alis-alis, perona pipi, lipstik, gecek dan serinata. Untuk pengantin pria menggunakan riasan yang natural yaitu: foundation tipis, bedak, eyeshadow warna natural, alis-alis, lipstik dan gecek.

Tatanan rambut pengantin Bali pada umumnya menggunakan bunga sandat emas sebagai bunga utamanya. Tatanan rambut pengantin Madya khas Kabupaten Jembrana terdiri dari: semi capit udang, bunga menori putih yang memiliki fungsi sebagai penyangga bunga bancangan, sanggul gelung tanduk, ketiganya merupakan ciri khas dari tata rias pengantin Jembrana. Bunga sandat emas, puspo lembo, bancangan, bunga kap, bunga cempaka putih, cempaka kuning, dan terakhir bunga sandat. Bunga cempaka putih, kuning dan sandat melambangkan Tri 
Murti (brahma, wisnu dan iswara) yang memiliki fungsi untuk memberikan aroma harum dan kesegaran pada pengantin wanita. Sedangkan tatanan rambut pengantin Bali Madya menggunakan bunga cempaka putih, kuning yang dipasang pada bagian depan, menggunakan semi, serta sanggul gelung muding yang dipasang pada bagain belakang (Mertami.1993,32). Jadi kesimpulannya bahwa tata rias pengantin Bali Madya Memiliki perbedaan dengan tata rias pengantin Bali Madya khas Kabupaten Jembrana. Tatanan rambut untuk pengantin pria dalam tata rias pengantin Bali Madya khas Kabupaten Jembrana tidak memiliki penataan khusus hanya saja rambut yang disisr rapi dan diberikan hair spray.

Busana yang digunakan pada tata rias pengantin Bali Madya khas Kabupaten Jembrana sebagian besar menggunakan kain tenunan khas Kabupaten Jembrana seperti: tapih wali tenuan khas Jembrana yang memiliki makna sebagai lambang masa muda dari seorang pengantin, kamben songket motif cerari kotak, selendang rujak boni dan mastuli hitam, serta selendang tenunan motif jembatan cinta khas Kabupaten Jembrana. Sedangkan pada tata rias pengantin Bali Madya sebagian besar menggunakan kain prada seperti; tapih prada, kamben prada, betbet dan selendang prada (Mertami.1993,44). Jadi kesimpulannya bahwa tata rias pengantin Bali Madya dengan tata rias Pengantin Bali Madya khas Kabupaten Jembrana Memiliki perbedaan dari penggunaan kainnya. Untuk busana pengantin pria dalam tata rias pengantin Bali Madya khas Kabupaten Jembrana menggunakan, kamben, saput, stagen, umpal dan udeng.

Aksesoris yang digunakan juga memiliki perbedaan, pada tata rias pengantin Madya khas Kabupaten Jembrana pengantin wanita menggunakan subeng cerorot, kalung binar yang memiliki jumlah liontin 9 buah, dan gelang nagasatru. Pengantin pria menggunakan rumbing, bros binar, bunga pucuk emas dan keris. Sedangkan pada tata rias pengantin Bali Madya menggunakan aksesoris berupa: gelang nagasatru, subeng cerorot, dan cincin. Pengantin pria menggunakan rumbing, gelang tangan, cincin, dan keris.
(Mertami. 1993,55). Jadi kesimpulannya bahwa tata rias pengantin Bali Madya dengan tata rias pengantin Bali Madya Jembrana memiliki perbedaan dalam penggunaan aksesorisnya.

Menurut pendapat dari Mertami (2003:14) yang menyatakan bahwa tata rias dan busana di masing-masing Kabupaten memiliki perbedaan, dan ciri khas tersendiri. Perbedaan dan ciri khas dari tata rias pengantin Madya khas Kabupaten Jembrana dapat dilihat dari penggunaan sanggul gelung tanduk yang memiliki makna sebagai simbol keberanian yang menandakan pengantin harus kuat dalam menghadapi kehidupan barunya. Sanggul gelung tanduk ini dijadikan ciri khas pada tata rias pengantin Jembrana karena pada zaman dahulu di Kabupaten Jembrana memiliki budaya dan tradisi makepungkepungan menggunakan kerbau, dari budaya tersebut tanduk kerbau yang digunakan sebagai ciri khas dari pengantin Madya khas Kabupaten Jembrana, sehingga sanggul dalam tata rias pengantin Jembrana menyerupai tanduk kerbau yang dipasang pada bagain belakang. bunga menori putih memiliki makna sebagai lambang kesucian dan pada zaman dulu di daerah Jembrana hanya bunga menori yang di temukan dan dapat hidup di daerah kering, sehingga bunga menori dijadikan bunga yang harus ada dalam tata rias pengantin Madya khas Kabupaten Jembrana dan dijadikan sebagai ciri khasnya. Semi dalam tata rias pengantin Madya khas Kabupaten Jembrana memiliki bentuk keluar percis menyerupai capit udang, sehingga dalam tata rias pengantin Madya khas Kabupaten Jembrana disebut dengan semi capit udang yang memiliki makna sebagai lambang keseimbangan dimana ketika seseorang telah menikah haruslah memiliki sikap seimbang antara pikiran, tubuh dan jiwanya.

Perbedaan juga dapat dilihat dari tingkatan di setiap Kabupaten yang ada di Bali. Hasil penelitian yang dilakukan oleh Dwi Pujiastuti (2015) dengan judul tentang "Tata Rias dan Busana Pengantin Bali Gaya Badung" menjelaskan bahwa tata rias dan busana pengantin Bali gaya Badung adalah suatu tata rias yang kental dengan pakemnya sejak dulu. Dalam penggunaan tata rias pengantin gaya Badung memiliki 
tiga tingkatan salah satunya tingkatan menengah (Madya) yang dapat digunakan dalam upacara pernikahan atau potong gigi. Tata rias Madya Badung meliputi: alis-alis, semi, gecek, sanggul/gelung moding, dan serinata, hiasan kepala meliputi: bancangan, puspa lembo, bunga sandat emas, bunga cap, kompyong, bunga mawar, cempaka putih, kuning, bunga sasak. Hiasan pada badan meliputi: tapih, kamben, stagen, sabuk prada, selendang, subeng, dan gelang nagasatru. Busana pengantin pria meliputi: kampuh/saput, kamben, umpal dan udeng.

Selanjutnya diperkuat lagi dari hasil penelitian yang dilakukan oleh Ni Putu Putri Astuti (2017) dengan judul "tata rias pengantin Kabupaten Klungkung" menjelaskan bahwa tata rias pengantin Kabupaten Klungkung memiliki bagianbagain tata rias wajah yang meliputi: serinata, alis-alis, hiasan mata, hidung perona pipi. Pada tatanan rambut menggunakan semi lilit/gulung, bunga sari konta, bunga mawar, cempaka putih, kuning, sandat, bunga reong emas, sanggul kletek mandel. Busana yang digunakan tapih prada, sabuk prada, kamben prada, selendang prada, dan aksesoris yang digunakan yaitu: sabuk bebekeng, subeng, gelang, tapel pelengan dan keris.

Selanjutnya dari hasil penelitian yang dilakukan oleh Ni Kadek Lina Wiarti (2015) yang berjudul "Tata Rias Pengantin Agung Kabupaten Karangasem Provinsi Bali" yang menjelaskan bahwa tata rias pengantin Agung Karangasem di bagai menjadi tiga bagain yaitu tata rias wajah rambut, busana dan aksesoris pengantin. Tata rias pengantin Agung Karangasem memiliki keunikan tersendiri, yang dapat dilihat dari segi penataan bunga dan jenis bunga yang digunakan, penggunaan busana serta bagian-bagian dari tata rias pengantin Agung Karangasem yang dipercayai oleh masyarakat di Kabupaten Karangasem. Adapun ciri khas dari tata rias pengantin Agung Karangasem yaitu menggunakan empak-empak yang berbeda dengan tata rias pengantin di kabupaten lain, blengker yang digunakan memiliki makna yaitu sebagai pengikat indria, dan sanggul gento agung berbentuk angka delapan yang sering disebut dengan pusung ngandang, dan sekar taji.
Selanjutnya penelitian yang dilakukan oleh Clarina Novi Olgaria (2017) yang berjudul "Kajian Tata Rias Pengantin Tradisional Jember Sari Jawa Timur" yang menjelaskan bahwa bnetuk dari tata rias pengantin tradisional Jember Sari sebagian besar terinspirasi dari hasil komoditi alam kota Jember yaitu daun tembakau. Tata rias wajah dari pengantin tradisional putri menggunakan riasan pada dahi yang disebut dengan paes yang berbentuk bulat telur, rontoso, dan godek. Penataan rambut menggunakan sanggul tawangrinenggo dengan aksesoris tusuk anda puspa, ndok remek, bando, sisir melati, dan renggan. Busana dan aksesoris tubuh pengantin meliputi: kebaya kutu baru, kain motif rontoso dan aksesoris cincin, anting, gelang, kalung, bros susun tiga, dan selop. Dari hasil penelitian ini menyatakan bahwa adanya perbedaan di setiap daerah dan disetiap Kabupaten di Bali memiliki perbedaan antara tingkatan pengantin yang memiliki ciri khas, dan keunikan yang dimiliki dari masing-masing Kabupaten yang ada di Bali.

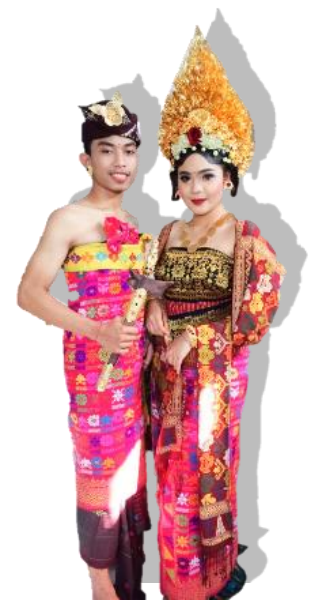

Gambar 10. Pengantin Madya Jembrana

\section{KESIMPULAN DAN SARAN}

Berdasarkan dari hasil penelitan yang dilakukan di atas maka dapat disimpulkan bahwa tata rias pengantin Bali Madya khas Kabupaten Jembrana merupakan tata rias yang tingkatannya berada di tengah-tengah yang dapat dikatakan riasan yang terlihat sederhana tetapi masih memperlihatkan kemewahannya yang dapat digunakan dalam upacara pernikahan (pawiwahan) dan upacara potong gigi (mepandes) di Kabupaten Jembrana. Tata rias pengantin Bali Madya khas Kabupaten Jembrana terdiri 
dari tata rias wajah, tatanan rambut, busana serta aksesoris yang digunakan, tata rias ini memiliki keunikan dan ciri khas yang dapat membedakannya dengan tata rias yang ada di Kabupaten lain. Tata rias wajah pengantin Madya khas Kabupaten Jembrana pada pengantin wanita meliputi: penggunaan serinata, alis-alis, eye shadow, perona pipi, lipstik, dan gecek merah pada dahi pengantin. Pada pengantin pria menggunakan riasan yang natural seperti penggunaan foundation tipis, eyeshadow warna natural, alis-alis, lipstik dan gecek. Tatanan rambut dalam tata rias pengantin wanita yaitu: semi capit udang, sanggul gelung tanduk, bunga menori putih, bunga sandat emas, bancangan, puspo lembo, bunga kap, bunga mawar merah, bunga cempaka putih, kuning dan sandat. Pada pengantin pria tidak ada penataan khusus hanya saja rambut yang disisr rapi dan di berikan hair spray. Busana yang digunakan pengantin wanita yaitu meliputi: tapih wali, kamben cerari kotak, selendang rujak boni, selendang mastuli hitam, dan selendang jembatan cinta, untuk pengantin pria meliputi: kamben, saput, stagen, umpal dan udeng. Terakhir penggunaan aksesoris dalam tata rias pengantin Bali Madya khas Kabupaten Jembrana pada pengantin wanita meliputi: subeng cerorot, kalung binar, gelang nagasatru, sedangkan untuk pengantin pria menggunakan rumbing, bunga pucuk emas, dan keris.

\section{SARAN}

Berdasarkan pembahasan hasil penelitian dan penarikan kesimpulan, maka dapat diajukan saran sebagai berikut:

1. Bagi masyarakat: agar nantinya masyarakat dapat mengenal dan dapat memotivasi untuk tetap mempertahankan budaya terutama dalam tata rias pengantin Madya khas Kabupaten Jembrana dengan baik sehingga generasi selanjutnya dapat menjaga dan melestarikannya.

2. Bagi peneliti lain: penelitian ini penulis buat untuk dapat dijadikan acuan oleh peneliti lain yang akan mengambil peneltian tentang tata rias pengantin Madya, dan dapat dijadikan kajian pustaka untuk membandingkan tata rias pengantin Madya yang ada di Kabupaten lain.

3. Bagi mahasiswa: agar mahasiswa dapat mempraktekan dan mengaplikasikannya dengan baik dan benar.

\section{DAFTAR RUJUKAN}

Agung, Ayu Ketut Agung. 2004. Busana Adat Bali. Denpasar: Pustaka Bali Post.

Hermayani, Kadek, 2019. Tata Rias Penagntin Agung Jembrana. e-jurnal Bosaparis Universitas Pendidikan Ganesha. Vol 10. No 2.

Mertami, Nyonya M. 1993. Tata Rias Pengantin Bali. Denpasar: PT. Upada Sastra.

Mertami, Nyonya M. 2003. Tata rias Pengantin Bali. Denpasar: PT. Upada Sastra.

Mahligai. 2009. Inspirasi Pengantin Bali. Denpasar: DieriArt Lab. Bali: Jagad Art Space.

Noviana, Mila. 2015. Hubungan Pengetahuan Rias Wajah Sehari-hari dengan Menggunakan Kosmetika Tata Rias Wajah di SMK Negeri 3 Klaten. ejurnal Keluarga. Vol 1. No 2.

Puspa, Camerina. 2013. Broadcast MakeUp. Jakarta: PT Gramedia Pustaka.

Pujiastuti, Ni Kadek. 2015. Tata Rias dan Busana Pengantin Bali Gaya Badung. e-jurnal Bosaparis Universitas Pendidikan Ganesha. Vol 12. No 1.

Putri Astuti, Ni Putu. 2017. Tata Rias Pengantin Kabupaten Klungkung. ejurnal Bosaparis Universitas Pendidikan Ganesha. Vol 8. No 2.

Seriati, Ni Nyoman. 2011. Tata Rias dan Busana. Yogyakarta: Universitas Negeri Yogyakarta.

Wiartini, Kadek Lina. 2016. Tata Rias Pengantin Agung Kabupaten Karangasem Provinsi Bali. e-jurnal 
Jurnal Bosaparis: Pendidikan Kesejahteraan Keluarga

Volume 12, Nomor 1, Maret 2021

p-ISSN : 2599-1434

e-ISSN : $\overline{2599-1442}$

Bosaparis Universitas Pendidikan

Ganesha. Vol 1. No 2.

Novia, Clarina. 2015. Kajian Tata Rias Pengantin Tradisional Jember Sari Jawa Timur. e-jurnal Universitas Negeri Surabaya. Vol 6. No 3. (Hlm 43-51) 